\title{
Least limiting water range in Spodosol and initial growth of sugarcane under soil bulk densities and salinities
}

\author{
Raphaela R. Bezerra ${ }^{1}$, Ênio F. de F. e Silva ${ }^{1}$, Glécio M. Siqueira ${ }^{2}$, Daniel da C. Dantas ${ }^{1}$, \\ Brivaldo G. de Almeida ${ }^{3}$ \& Alexsandro O. da Silva ${ }^{4}$ \\ ${ }^{1}$ Universidade Federal Rural de Pernambuco/Programa de Pós-Graduação em Engenharia Agrícola. Recife, PE, Brasil. E-mail: raphaelarevoredo38@gmail.com \\ - ORCID: 0000-0002-5287-694X; effsilva@uol.com.br - ORCID: 0000-0002-8652-503X; d1cdantas@hotmail.com (Corresponding author) - ORCID: 0000-0002- \\ 2459-9877 \\ ${ }^{2}$ Universidade Federal do Maranhão/Departamento de Geociências. São Luis, MA, Brasil. E-mail: gleciosiqueira@hotmail.com - ORCID: 0000-0002-3513-2658 \\ ${ }^{3}$ Universidade Federal Rural de Pernambuco/Departamento de Agronomia. Recife, PE, Brasil. E-mail: brivaldoalmeida@gmail.com - ORCID: 0000-0003-3260-0767 \\ ${ }^{4}$ Universidade Federal do Ceará. Fortaleza, CE, Brasil. E-mail: alexsandro@ufc.br - ORCID: 0000-0001-5528-9874
}

\begin{abstract}
The impacts of agricultural mechanization and soil management on sugarcane activity may compromise the growth of plants. This study aimed to evaluate the initial growth of sugarcane (Saccharum officinarum) at soil densities under two salinity conditions, associated with the least limiting water range (LLWR), and obtain the critical density for the Spodosol. The treatments consisted of the use of five bulk densities $\left(1.40 ; 1.50 ; 1.60 ; 1.70\right.$ and $\left.1.80 \mathrm{Mg} \mathrm{m}^{-3}\right)$ and two conditions of soil salinity (ECse $=0.5$ and $3.0 \mathrm{dS} \mathrm{m}^{-1}$. Morphological variables and biomass of sugarcane plants were measured and, simultaneously, undisturbed soil samples were collected in the layers of $0.02-0.08 \mathrm{~m}$ to determine the water retention curve, soil resistance to penetration and the least limiting water range. In general, it was concluded that sugarcane plants has higher growth between the bulk densities of 1.50 and $1.60 \mathrm{Mg} \mathrm{m}^{-3}$. The salinized soil showed higher LLWR than the non-salinized soil, leading to higher shoot fresh mass at bulk densities between 1.49 and $1.66 \mathrm{Mg} \mathrm{m}^{-3}$. The critical bulk densities observed for the Spodosol were $1.70 \mathrm{Mg} \mathrm{m}^{-3}$ for the non-salinized soil and $1.77 \mathrm{Mg} \mathrm{m}^{-3}$ for the salinized soil.
\end{abstract}

Key words: Saccharum officinarum, soil compaction, soil resistance to root penetration, soil physical quality

\section{Intervalo Hídrico Ótimo em Espodossolo e crescimento inicial da cana-de-açúcar sob densidades aparentes e salinidade do solo}

RESUMO: Os impactos da mecanização agrícola e o manejo do solo na atividade canavieira podem comprometer o crescimento das plantas. O objetivo deste estudo foi avaliar o crescimento inicial da cana-de-açúcar (Saccharum spp.) sob densidades do solo em duas condições de salinidade, associado ao intervalo hídrico ótimo (IHO) e obter a densidade crítica para o Espodossolo. Os tratamentos consistiram da utilização de cinco densidades de solo $\left(1,40 ; 1,50 ; 1,60 ; 1,70\right.$ e 1,80 $\left.\mathrm{Mg} \mathrm{m}^{-3}\right)$ e duas condições de salinidade do solo (CEes = 0,5 e 3,0 dS $\mathrm{m}^{-1}$ ). Realizaram-se medições de variáveis morfológicas e massa vegetal das plantas de cana-de-açúcar e paralelamente coletaram-se amostras indeformadas de solo nas camadas de 0,02-0,08 m, para determinação da curva de retenção de água, da resistência do solo à penetração e o intervalo hídrico menos limitante. Concluiu-se de forma geral que houve maior crescimento das plantas entre as densidades de solo de 1,50 e 1,60 $\mathrm{Mg} \mathrm{m}^{-3}$. O solo salinizado apresentou maior IHO que o solo não salinizado, refletindo em maior massa fresca da parte aérea para valores de densidades do solo entre 1,49 e 1,66 $\mathrm{Mg} \mathrm{m}^{-3}$. As densidades críticas observadas para o Espodossolo foram de $1,70 \mathrm{Mg} \mathrm{m}^{-3}$ para o solo não salinizado e de $1,77 \mathrm{Mg} \mathrm{m}^{-3}$ para o solo salinizado.

Palavras-chave: Saccharum officinarum, compactação do solo, resistência do solo à penetração de raízes, qualidade física do solo 


\section{INTRODUCTION}

The excess of mechanized operations causes changes in soil physical structure, leading to compaction (Cavichioli et al., 2012; Souza et al., 2014), which is indicated as one of the factors of soil physical quality (Betioli Júnior et al., 2012).

Soil physical quality is associated with the capacity of a soil to provide adequate conditions for plant production (Moreira et al., 2014). Attributes such as bulk density (Bd), porosity, water content $(\theta)$ and tensile strength of aggregates are used as indicators in agricultural production systems (Collares et al., 2011), besides the compaction index (CI), calculated by the ratio between bulk density $(\mathrm{Bd})$ and maximum density $\left(\mathrm{D}_{\mathrm{MP}}\right)$ determined in the Proctor compaction test (PCT) (Barber et al., 1989).

Working with artificially compacted Oxisols, Romero et al. (2014) found that CI within the range from 0.70 to $0.85 \mathrm{did}$ not cause restrictions to plant growth.

The effects of soil compaction on density, porosity, water retention and mechanical resistance to penetration can be integrated into a single index, the least limiting water range (LLWR) (Silva et al., 1994; Tormena et al., 1998).

According to Collares et al. (2006), the LLWR provides ideal conditions for development between the lower and upper limits, with limiting conditions below and above these limits, and the critical condition occurs when the LLWR is null. The LLWR does not need to be null to indicate physical degradation (Blainski et al., 2012).

On the other hand, some researchers have criticized the LLWR regarding its lower limit, since the volumetric water content at the permanent wilting point $\left(\theta_{\mathrm{PWP}}\right)$ does not represent the soil water content which is adequate for crop development (Gubiani et al., 2013).

Soil salinity is another factor influencing crop yield, because of the reduction in the water potential resulting from the contribution of the osmotic potential, leading to reduction of leaf area and, consequently, to lower water consumption by crops (Silva et al., 2013; Lira et al., 2018).

In this context, the objectives of this study were to evaluate the influence of salinized soil on the least limiting water range (LLWR), to establish the values of critical bulk density (Bdc), and to evaluate the initial growth of sugarcane under different bulk density (Bd) and salinities.

\section{Material ANd Methods}

The experiment was carried out in the period from June to September 2016, in a greenhouse of the Federal Rural University of Pernambuco (UFRPE), Agricultural Engineering Department, located at $8^{\circ} 01^{\prime} 05^{\prime \prime} \mathrm{S}$ and $34^{\circ} 56^{\prime} 48^{\prime \prime} \mathrm{W}$, and altitude of $6.5 \mathrm{~m}$.

The physico-chemical characteristics of the soil used in the experiment are: coarse sand $=640 \mathrm{~g} \mathrm{~kg}^{-1}$, fine sand $=250 \mathrm{~g} \mathrm{~kg}^{-1}$, silt $=30 \mathrm{~g} \mathrm{~kg}^{-1}$ and clay $=80 \mathrm{~g} \mathrm{~kg}^{-1}$; textural classification $=$ loamy sand; clay dispersed in water $=0 \%$; degree of flocculation $=100 \% ; \mathrm{pH}($ water $)=5.0 ; \mathrm{Ca}^{2+}=0.3 \mathrm{cmol}_{\mathrm{c}} \mathrm{dm}^{-3}, \mathrm{Mg}^{2+}=0.4$ $\mathrm{cmol}_{\mathrm{c}} \mathrm{dm}^{-3}, \mathrm{Na}^{+}=0.11 \mathrm{cmol}_{\mathrm{c}} \mathrm{dm}^{-3}, \mathrm{~K}^{+}=0.02 \mathrm{cmol}_{\mathrm{c}} \mathrm{dm}^{-3} ; \mathrm{SB}$ $=0.83 \mathrm{cmol}_{c} \mathrm{dm}^{-3} ;$ effective CEC $=1.58 \mathrm{cmol}_{\mathrm{c}} \mathrm{dm}^{-3} ; \mathrm{m}=5 \%$;
$\mathrm{ESP}=6.96 \%$; organic carbon $=11.92 \mathrm{~g} \mathrm{~kg}^{-1}$; assimilable $\mathrm{P}=$ $5 \mathrm{mg} \mathrm{dm}^{-3} ; \theta_{0.1 \mathrm{~atm}}=16.34 \% ; \theta_{15 \mathrm{~atm}}=5.03 \%$; maximum Proctor density $\left(\mathrm{D}_{\mathrm{MP}}\right)=1.92 \mathrm{Mg} \mathrm{m}^{-3}$.

The experimental design was completely randomized in a $5 \times 2$ factorial scheme. Treatments consisted of the combination of five bulk density, $1.40,1.50,1.60,1.70$ and $1.80 \mathrm{~kg} \mathrm{~m}^{-3}$, which correspond to the compaction indices $0.73,0.78,0.83,0.89$ and 0.94 , respectively (defined by the relationship between bulk density and the maximum density obtained in the Proctor compaction test) and two levels of soil salinity (S1 $=0.5$ and $\mathrm{S} 2=$ $3.0 \mathrm{dS} \mathrm{m}^{-1}$ ), with four repetitions, totaling 40 experimental units.

Each experimental unit consisted of two pots, which were graduated at every $0.05 \mathrm{~m}$ and filled with artificially compacted soil layers.

The mass of dry soil (MDS) to be used to fill the pots for each bulk density (Bd) was obtained from the data of pot volume and $\mathrm{Bd}$, according to Eq. 1.

$$
\mathrm{MDS}=\mathrm{Vt} \mathrm{Bd}
$$

where:

MDS - mass of dry soil, Mg;

$\mathrm{Vt}$ - total volume of the pot, which in this case was considered at every $0.05 \mathrm{~m}, \mathrm{~m}^{3}$; and,

Bd - bulk density, $\mathrm{Mg} \mathrm{m}^{-3}$.

With the value of volumetric water content at field capacity $\left(\theta_{\mathrm{FC}}=30 \%\right)$, the gravimetric water content $(\mathrm{U})$ was calculated for each level of soil density (Eq. 2). Subsequently, for the MDS, the mass of water $(\mathrm{Mw})$ needed to be added to the soil and bring it to field capacity $\left(\mathrm{U}_{\mathrm{FC}}\right)$ was obtained (Eq. 3).

$$
\begin{gathered}
\mathrm{U}_{\mathrm{FC}}=\frac{\theta_{\mathrm{FC}}}{\mathrm{Bd}} \\
\mathrm{Mw}=\frac{\mathrm{U}_{\mathrm{FC}} \mathrm{MDS}}{100}
\end{gathered}
$$

where:

$\mathrm{U}_{\mathrm{FC}}$ - gravimetric water content at field capacity, \%;

$\theta_{\mathrm{FC}} \quad$ - volumetric water content at field capacity, \%;

$\mathrm{Bd}$ - bulk density, $\mathrm{g} \mathrm{cm}^{-3}$;

Mw - mass of water, g; and,

MDS - mass of dry soil, g.

In the plots with salinized soil (S2), the salts were added at the same time as the water content of the soil in the pots was raised to field capacity, by diluting in the water the quantity of salts required to be added according to Richards (1954) (Eq. 4), using $\mathrm{NaCl}$ and $\mathrm{CaCl}_{2}$ at 1:1 molar proportion of $\mathrm{Na} / \mathrm{Ca}$ in the water from the local supply.

$$
\mathrm{QS}=\mathrm{ECse} 640 \mathrm{Vs}
$$

where:

QS - quantity of salts applied, mg;

ECse - electrical conductivity of the saturation extract,

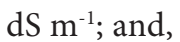

Vs - water volume at soil saturation, L. 
For planting, two setts of sugarcane, RB867515 variety, were used per pot and, after germination, thinning was performed, maintaining one plant per pot.

Irrigation management was carried out by replacing the water volume required to bring soil moisture to field capacity (here assumed as pot capacity), which was obtained by the difference between the volume of water applied and the volume drained, based on the average of ten pots. The water used for irrigation came from the municipal supply system of UFRPE $\left(\mathrm{EC} \approx 0.5 \mathrm{dS} \mathrm{m}^{-1}\right)$.

To determine the soil water retention curve (SWRC), soil resistance to penetration curve (SRPC) and aeration porosity for least limiting water range (LLWR) estimation, six undisturbed soil samples were collected in the 0-0.10 m layer of each pot, using stainless-steel volumetric rings (volume = $100 \mathrm{~cm}^{3}$ ), in a total of 240 samples (24 per treatment).

The samples were saturated for $24 \mathrm{~h}$ and subjected to tensions of 1,6 and $10 \mathrm{kPa}$ on a tension table (Romano et al., 2002) and 33.3, 80, 300, 500 and $1500 \mathrm{kPa}$, with pressures applied to porous plates (Dane \& Hopmans, 2002). After reaching equilibrium, the samples were used to determine soil resistance to root penetration (RP), using an electronic benchtop penetrometer with a metal rod at the end (Tormena et al., 1998).

Subsequently, the samples were subjected to drying at $105^{\circ} \mathrm{C}$ for $24 \mathrm{~h}$, in order to measure the masses of water and solids of the soil. The $\mathrm{Bd}$ was determined by the relationship between the mass of solids and the ring volume, while $\theta$ was obtained from the relationship between the volume of water in equilibrium in the sample and the volume of soil.

The soil resistance to penetration curve was fitted according to Busscher (1990). Subsequently, it was fitted using the nonlinear model employed by Ross et al. (1991), incorporating Bd into the model.

To determine the LLWR, the following limits were considered: volumetric water content at field capacity $\left(\theta_{\mathrm{FC}}\right)$, volumetric water content at permanent wilting point $\left(\theta_{\mathrm{PWP}}\right)$, assumed as the water contents retained in the soil at tensions of 10 and $1500 \mathrm{kPa}$, respectively; the volumetric water content of the soil at which the penetration resistance reaches $2.0 \mathrm{MPa}$ $\left(\theta_{\mathrm{RP}}\right)$ and the volumetric water content of the soil at which the aeration porosity is $0.10 \mathrm{~m}^{3} \mathrm{~m}^{-3}\left(\theta_{\mathrm{AP}}\right)$.

The critical values of the water contents at $\theta_{\mathrm{FC}}$ and at $\theta_{\mathrm{PWP}}$ were calculated according to Eqs. 5 and 6, respectively.

$$
\begin{gathered}
\theta_{\mathrm{FC}}=\exp ^{(\mathrm{a}+\mathrm{b} \mathrm{Bd})} \varnothing_{\mathrm{FC}}^{\mathrm{c}} \\
\theta_{\mathrm{PWP}}=\exp ^{(\mathrm{a}+\mathrm{b} \mathrm{Bd})} \varnothing_{\mathrm{PWP}}^{\mathrm{c}}
\end{gathered}
$$

where:

$\theta_{\mathrm{FC}} \quad$ - volumetric water content at field capacity, $\mathrm{m}^{3} \mathrm{~m}^{-3}$;

$\theta_{\text {PWP }}$ - volumetric water content at permanent wilting point, $\mathrm{m}^{3} \mathrm{~m}^{-3}$;

$\mathrm{Bd}$ - soil bulk density, $\mathrm{Mg} \mathrm{m}^{-3}$;

$\varnothing_{\mathrm{FC}}$ - matric potential applied at field capacity, $\mathrm{kPa}$;

$\varnothing_{\text {PWP }}$ - matric potential applied at permanent wilting point, $\mathrm{kPa}$; and,

a, b, c - fitting parameters of the model proposed by Ross et al. (1991).
The LLWR was calculated by the difference between the upper and lower limits of the water contents at which the physical parameters considered occur. The upper limit is the lowest value of $\theta$ considered $\theta_{\mathrm{FC}}$ or aeration porosity $\left(\theta_{\mathrm{AP}}\right)$, and the lower limit is the highest value considering penetration resistance $\left(\theta_{\mathrm{RP}}\right)$ or $\theta_{\mathrm{PWP}}$.

The Bdc for crop development was obtained when the upper and lower limits of LLWR were numerically equal, where LLWR is null.

In the period from 30 to 72 days after planting (DAP), culm diameter (CD) and plant height $(\mathrm{PH})$ were weekly evaluated. At 72 DAP, plants were collected to evaluate their shoot fresh and dry masses (SFM), shoot dry mass (SDM) and root dry mass (RDM).

For the variables $\mathrm{CD}$, and $\mathrm{PH}$, the sphericity test was applied to define the type of analysis to be used: univariate with split-plots, or multivariate with repeated measurements in time. The multivariate analysis with repeated measurements in time was used by applying the Wilk's Lambda, Pillai's Trace, Hotelling-Lawley Trace and Roy's Greatest Root tests, considering whether the effect was significant or not, based on the results of the majority. To establish a model that represents the phenomenon under study, the Student's t-test $(\mathrm{p}<0.05)$ was used to test the regression coefficients.

The yield variables SFM, SDM and RDM, the data were submitted to analysis of variance by $F$ test, and when significant $(\mathrm{p}<0.05)$, they were subjected to regression analysis using the Student's t-test $(\mathrm{p}<0.05)$ to test the regression coefficients.

\section{Results AND Discussion}

The multivariate analysis applied to the variables culm diameter (CD) and plant height (PH) showed significant effect ( $p \leq 0.01)$ according to the tests of Wilks, Pillai, HotellingLawley and Roy, for the vectors of treatment means, with isolated effect of time on $\mathrm{CD}$ and $\mathrm{PH}$, and effects of the interactions Salinity x Time on CD and Bd x Time on PH.

There was an increasing quadratic effect on $\mathrm{PH}$ as $\mathrm{Bd}$ increased, with a maximum value of $24.29 \mathrm{~cm}$ corresponding to $\mathrm{Bd}$ of $1.61 \mathrm{Mg} \mathrm{m}^{-3}$ and $\mathrm{DAP}=72$, and an increasing linear effect for time (DAP) (Figure 1).

These results differed from those obtained by Fagundes et al. (2014), who evaluated the initial growth of sugarcane cultivars under $\mathrm{Bd}$ and observed higher heights with $\mathrm{Bd}$ values of 1.28 and $1.30 \mathrm{Mg} \mathrm{m}^{-3}$.

Souza et al. (2014), evaluating the effect of four Bd values $\left(1.65,1.69,1.78\right.$ and $\left.1.82 \mathrm{Mg} \mathrm{m}^{-3}\right)$ on culm height, found no significant effect. Probably, in this case, there was no difference because the studied Bd values were high.

For $\mathrm{CD}$, there was an increasing linear effect as a function of DAP under both salinity conditions. For S1, there was an increase of $0.01907 \mathrm{~mm}$ in $\mathrm{CD}$, while for S2, this value was $0.0144 \mathrm{~mm}$ for every unit increase in DAP (Figure 2).

In studies with sugarcane under salinity, Simões et al. (2016) obtained a reduction of $8 \%$ in the CD due to the use of saline water $\left(8 \mathrm{dS} \mathrm{m}^{-1}\right)$, while Toledo et al. (2017) observed a decreasing linear effect on sugarcane evapotranspiration due to the higher $\mathrm{NaCl}$ concentration in the water used for irrigation. 


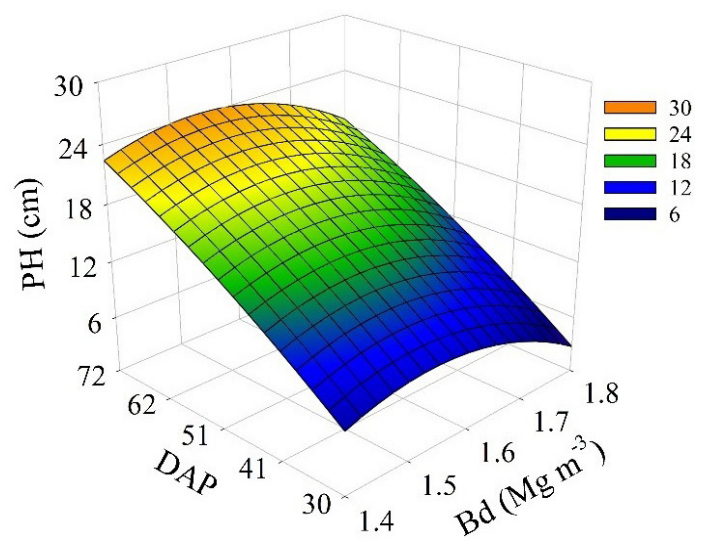

$\mathrm{PH}=-261.671+320.232^{* *} \mathrm{Bd}-98.985^{* *} \mathrm{Bd}^{2}+0.798^{* *} \mathrm{DAP}-0.263^{*} \mathrm{Bd}^{\mathrm{DAP}} \mathrm{R}^{2}=0.91$ *, ** - Significant at $\mathrm{p} \leq 0.05$ and $\mathrm{p} \leq 0.01$, respectively, by $\mathrm{F}$ test

Figure 1. Response surface for plant height $(\mathrm{PH})$ of sugarcane as a function of bulk density (Bd) and days after planting (DAP)

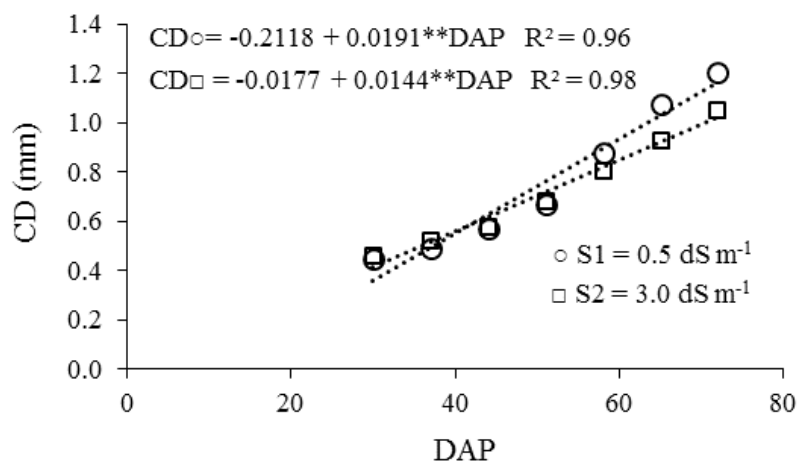

** - Significant at $\mathrm{p} \leq 0.01$ by F test

Figure 2. Culm diameter (CD) of sugarcane as a function of days after planting (DAP), cultivated under different levels of soil salinity

There was a significant effect $(\mathrm{p} \leq 0.01)$ of the interaction between the factors $\mathrm{Bd}$ and salinity on the variables shoot fresh mass (SFM) and root dry mass (RDM), as well as effects of $\mathrm{Bd}$ on SFM, shoot dry mass (SDM) and RDM, and of salinity on SFM and RDM (Table 1).

For $\mathrm{S} 1=0.5 \mathrm{dS} \mathrm{m} \mathrm{m}^{-1}$, a decreasing linear regression model was fitted (Figure 3A), which showed a reduction in SFM of 76.23 g per unit increase in Bd. For S2 $=3.0 \mathrm{dS} \mathrm{m}^{-1}$, with the fitted quadratic model, the maximum point was $100.73 \mathrm{~g}$ of SFM with Bd of $1.53 \mathrm{Mg} \mathrm{m}^{-3}$.

These results corroborate those obtained by Guimarães et al. (2013), Fagundes et al. (2014) and Labegalini et al. (2016) in studies with sugarcane, millet and corn crops, respectively, justified by the reduction of soil porosity, which compromises root development and also soil aeration.

Table 1. Analysis of variance for shoot fresh mass (SFM), shoot dry mass (SDM) and root dry mass (RDM) of sugarcane under bulk densities and salinity levels

\begin{tabular}{lccc|}
\hline \multirow{2}{*}{ Source of variation } & \multicolumn{3}{c|}{ F values } \\
\cline { 2 - 4 } Bulk density (Bd) & SFM & SDM & RDM \\
\hline Salinity (S) & $39.5^{\star *}$ & $4.27^{\star *}$ & $5.13^{\star *}$ \\
Bd x S & $15.61^{* *}$ & $0.46^{n s}$ & $8.42^{\star *}$ \\
CV (\%) & $10.02^{\star *}$ & $2.43^{\text {ns }}$ & $8.8^{\star *}$ \\
\hline
\end{tabular}

${ }^{* *}$ - Significant at $\mathrm{p} \leq 0.01{ }^{\text {ns }}$ - Not significant, respectively; CV - Coefficient of variation
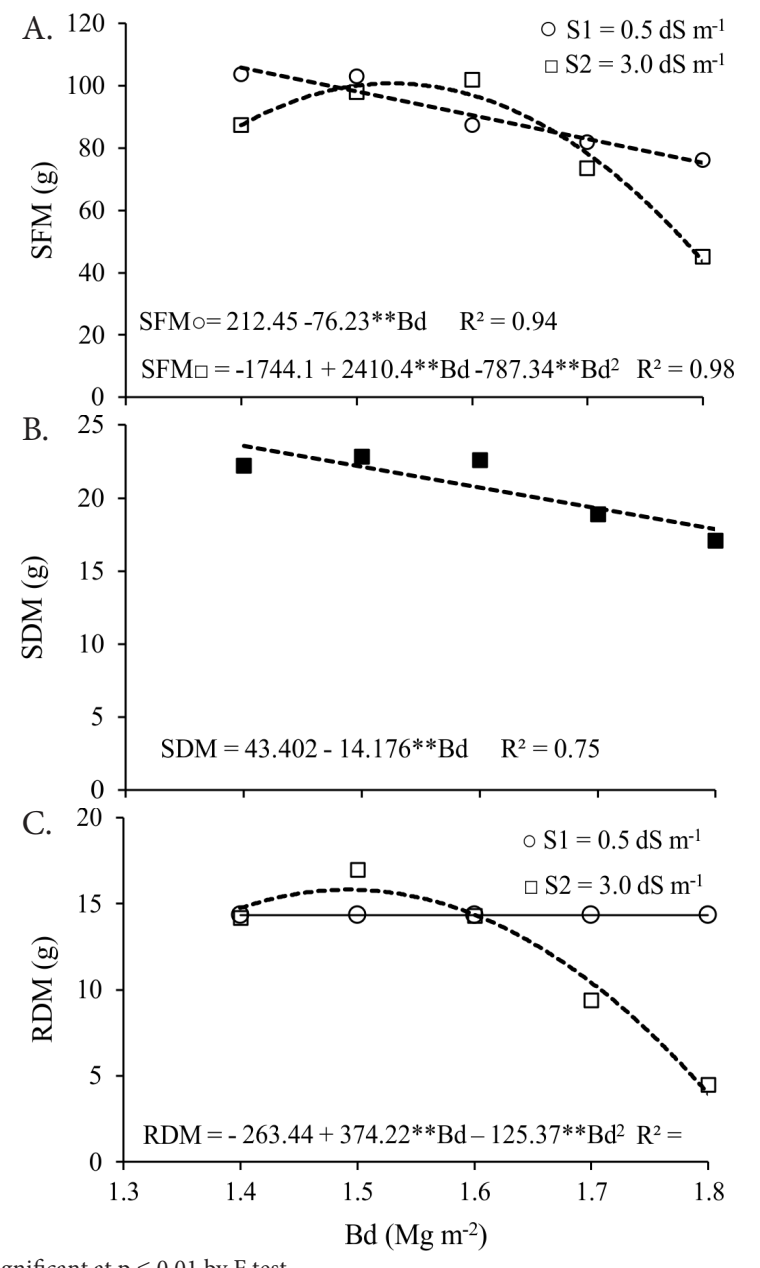

Figure 3. Shoot fresh mass (A), shoot dry mass (B) and root dry mass $(\mathrm{C})$ of sugarcane as a function of bulk densities $(\mathrm{Bd})$ at each salinity level and at 72 days after planting

There was a linear reduction in SDM as a function of the increase in $\mathrm{Bd}$, corresponding to $14.176 \mathrm{~g}$ per unit increase in Bd (Figure 3B). According to Medeiros et al. (2005), such reduction occurs due to changes in soil physical and hydraulic properties originated from the compaction, which reduce nutrient absorption and carbon accumulation by photosynthesis, thus affecting the development of the root system and aerial part of plants.

Similar results have also been verified by Bonfim-Silva et al. (2015), who obtained a reduction in SDM of $79.91 \%$ as Bd increased from 1.0 to $1.8 \mathrm{Mg} \mathrm{m}^{-3}$ in tests with jack bean, as well as Bonelli et al. (2011) and Fagundes et al. (2014), who observed reduction in the SDM of Mombasa grass and sugarcane with the increase of $\mathrm{Bd}$, respectively, the latter with maximum point at $\mathrm{Bd}$ of $1.33 \mathrm{Mg} \mathrm{m}^{-3}$.

For RDM, a quadratic model was fitted to the data for $\mathrm{S} 2$, with maximum point at $\mathrm{Bd}$ of $1.49 \mathrm{Mg} \mathrm{m}^{-3}$ with $\mathrm{RDM}$ of $15.81 \mathrm{~g}$ (Figure 3C). Similar results regarding the model were observed by Fagundes et al. (2014) with sugarcane and Ohland et al. (2014) with the jatropha crop.

The concept of LLWR encompasses a region where limitations to plant development are minimal. Water contents above or below the hatched area indicate limiting conditions to plant growth and critical conditions for development, and when $\mathrm{Bd}$ is greater than the critical bulk density $(\mathrm{Bdc}), \mathrm{LLWR}$ is zero. 
Hence, there were different effects due to the soil salinity conditions; in the non-salinized soil (Figure 4A), the aeration porosity $\left(\theta_{\mathrm{AP}}\right)$ represented the upper limit in more than $70 \%$, which corresponded to the $\mathrm{Bd}$ of up to $1.57 \mathrm{Mg} \mathrm{m}^{-3}$ (when it was replaced by $\left.\theta_{\mathrm{FC}}\right)$. On the other hand, in the salinized soil, this limit extended to $\mathrm{Bd}$ of $1.61 \mathrm{Mg} \mathrm{m}^{-3}$ (Figure $4 \mathrm{~B}$ ), and there was an increase of LLWR in the saline condition that favored greater water retention.

Regarding the lower limit, it corresponded to $\theta_{\mathrm{RP}}$ in more than $70 \%$ of the samples for the two salinity conditions tested, so that, in the non-salinized soil, the entire lower limit of LLWR was delimited by $\theta_{\mathrm{RP}}$ (Figure $4 \mathrm{~A}$ ). In the salinized soil, however, it was found that $\theta_{\mathrm{PWP}}$ was limiting only in the initial range of LLWR, between the $\mathrm{Bd}$ of 1.40 and $1.50 \mathrm{Mg}$ $\mathrm{m}^{-3}$ (corresponding only to $27 \%$ of all LLWR), when the $\theta_{\mathrm{RP}}$ started being limiting (Figure 4B). The great influence of the resistance to penetration on LLWR has also been observed by Silva et al. (1994) and Tormena et al. (1998), indicating that the soils are more degraded, with low structural quality, and, in the case under study, soils with more sandy texture.

Despite this, the LLWR obtained with the salinized soil promoted greater plant growth between $\mathrm{Bd}$ values of 1.50 and $1.66 \mathrm{Mg} \mathrm{m}^{-3}$, evidenced by the higher SFM within this interval
(Figure 3A). These results may be justified, probably, by the fact that the $\theta_{\mathrm{AP}}$ was, over a wider range of $\mathrm{Bd}$, the upper limit of LLWR in the salinized soil compared to the non-salinized soil, which had shorter range of LLWR and, consequently, lower water availability to plants. Regarding this, Araújo et al. (2004) commented that the reduction of $\theta_{\mathrm{AP}}$ leads to a reduction in the diffusion of oxygen, affecting the vegetative development.

Other studies with LLWR have not observed any relationship between higher LLWR and higher production of biomass (Collares et al., 2006; Klein \& Camara, 2007; Beutler et al., 2008). However, for the non-salinized soil, it was found that the $\mathrm{Bd}$ corresponding to the point of maximum RDM was $1.49 \mathrm{Mg} \mathrm{m}^{-3}$ (15.74 g, Figure 3C), precisely within the range of $\mathrm{Bd}$ referring to the region of highest water content (1.4 to 1.5 $\mathrm{Mg} \mathrm{m}^{-3}$ ) (Figure 4A).

In relation to critical bulk density (Bdc), it varied from $1.70 \mathrm{Mg} \mathrm{m}^{-3}$ for the non-salinized soil to $1.77 \mathrm{Mg} \mathrm{m}^{-3}$ for the salinized soil (Figure 4, dashed vertical lines), which correspond to 0.89 and 0.92 of the maximum proctor density $\left(\mathrm{D}_{\mathrm{MP}}\right)$, respectively. Romero et al. (2014), working with Oxisols obtained Bdc of 1.64 and $1.37 \mathrm{Mg} \mathrm{m}^{-3}$, which corresponded to 0.98 and 1.0 of the $\mathrm{D}_{\mathrm{MP}}$, respectively. The Bdc values found in the present study are consistent with those found by

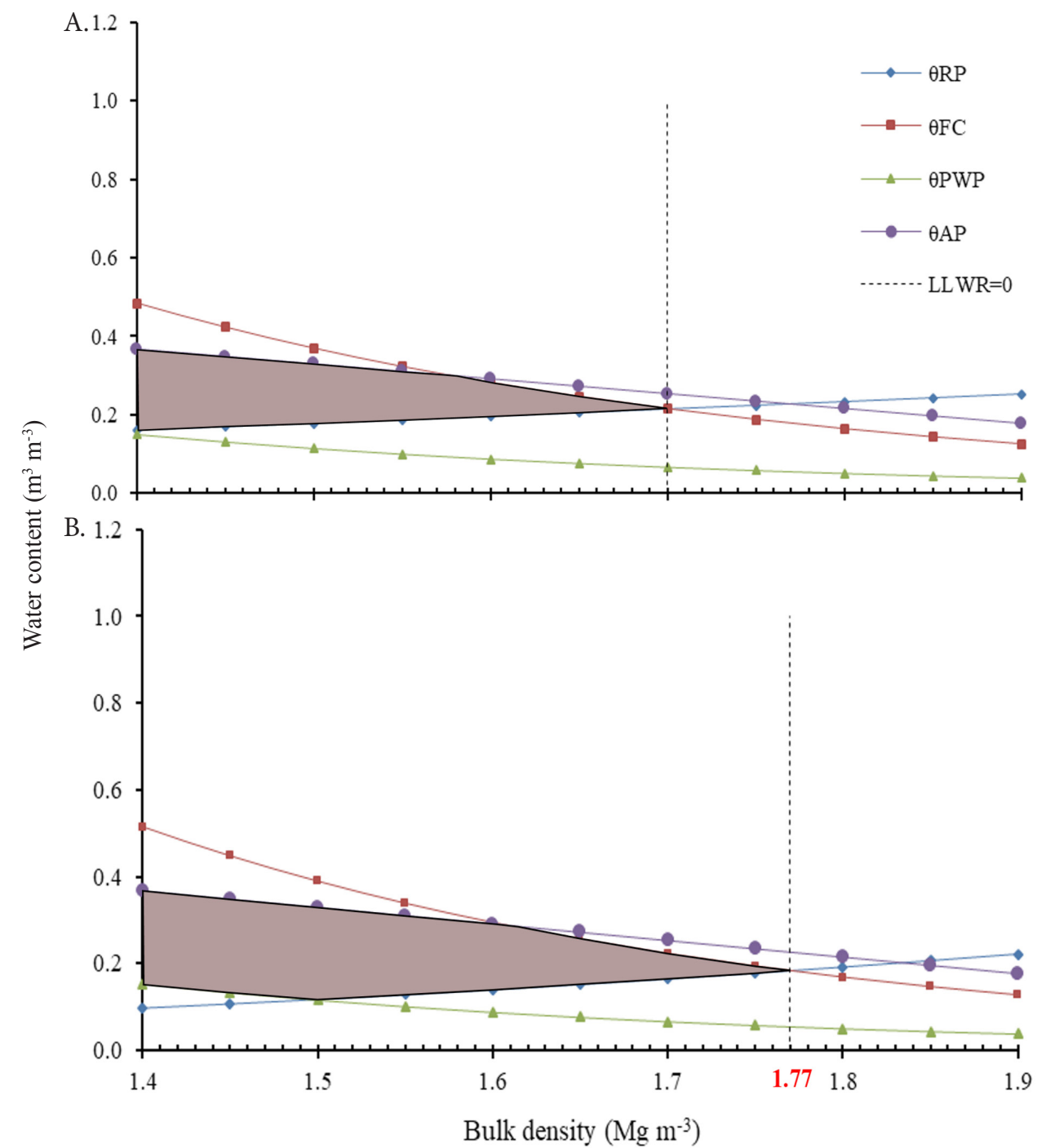

$\theta_{\mathrm{FC}}$ - volumetric water content at field capacity, $\mathrm{m}^{3} \mathrm{~m}^{-3} ; \theta_{\mathrm{PWP}}$ - volumetric water content at permanent wilting point, $\mathrm{m}^{3} \mathrm{~m}^{-3} ; \theta_{\mathrm{RP}}-$ volumetric water content of the soil at which the penetration resistance reaches $2.0 \mathrm{MPa} ; \theta_{\mathrm{AP}}$ - volumetric water content of the soil at which the aeration porosity is $0.10 \mathrm{~m}^{3} \mathrm{~m}^{-3}$; $\mathrm{Dashed}$ line indicates the critical bulk density (Bdc) Figure 4. Least limiting water range (LLWR) diagram in non-salinized soil (A) and in salinized soil (B) 
Collares et al. (2006), Bdc of $1.75 \mathrm{Mg} \mathrm{m}^{-3}$, and by Moreira et al. (2014), Bdc of $1.74 \mathrm{Mg} \mathrm{m}^{-3}$, working with sandy loam soil. When $\mathrm{Bd}>\mathrm{Bdc}$, from this value of $\mathrm{Bd}$, according to the definition of LLWR, the soil will exhibit severe physical degradation, which limits plant growth (Collares et al., 2008), requiring the adoption of recovery measures to make it productive.

The results of this study reveal that the increase of salinity in sandy soils (Figure 4B) increased the LLWR due to the reduction in the penetration resistance as soil density increased. Lima \& Grismer (1994) and Michelon et al. (2009) observed that soils that are sodic or in process of degradation, whose structure had been altered, showed an increase of density, in addition to a reduction of porosity as a consequence of the alteration in the volume resulting from the elimination of pores; with the reduction of macropores, which are very common and in large quantity in these soils, there will be greater availability of water to plants, resulting in greater production.

In addition, according to Medeiros et al. (2010), the accumulation of soluble salts makes the soil flocculated, soft and well permeable under moist conditions, allowing a lower resistance to root penetration and resulting in higher shoot fresh mass of sugarcane cultivated in the salinized soil. Therefore, the advantage of using LLWR has been highlighted, which is to allow the integration of physical factors directly related to plant growth, as well as to indicate the need for management practices that modify soil structure in order to broaden the LLWR.

\section{Conclusions}

1. From the least limiting water range and from the analyzed variables of the plant height, shoot fresh mass and root dry mass, it was found, in general, that there is a greater plant growth between the bulk densities of 1.50 and $1.60 \mathrm{Mg} \mathrm{m}^{-3}$.

2 . The salinized soil showed wider LLWR than the nonsalinized soil, resulting in greater shoot fresh mass between bulk density values of 1.50 and $1.66 \mathrm{Mg} \mathrm{m}^{-3}$.

3. In the soil with lower salinity, the critical bulk density was $1.70 \mathrm{Mg} \mathrm{m}^{-3}$, lower than that of the salinized soil, $1.77 \mathrm{Mg} \mathrm{m}^{-3}$.

\section{ACKNowledgments}

The authors express their gratitude to the CAPES for the financial aid for this research.

\section{Literature Cited}

Araújo, M. A.; Tormena, C. A.; Inoue, T. T.; Costa, A. C. S. Efeitos da escarificação na qualidade física de um Latossolo Vermelho distroférrico após treze anos de semeadura direta. Revista Brasileira de Ciência do Solo, v.28, p.459-504, 2004. https://doi. org/10.1590/S0100-06832004000300011

Barber, R. G.; Herrera, C.; Diaz, O. Compaction status and compaction susceptibility of alluvial soil in Santa Cruz, Bolivia. Soil \& Tillage Research, v.15, p.153-167, 1989. https://doi.org/10.1016/01671987(89)90071-8

Betioli Júnior, E.; Moreira, W. H.; Tormena, C. A.; Ferreira, C. J. B.; Silva, A. P. da; Giarola, N. F. B. Intervalo hídrico ótimo e grau de compactação de um Latossolo Vermelho após 30 anos sob plantio direto. Revista Brasileira de Ciência do Solo, v.36, p.971-982. 2012. https://doi.org/10.1590/S0100-06832012000300027
Beutler, A. N.; Centurion, J. F.; Silva, A. P. da; Centurion, M. A. P. da C.; Leonel, C. L.; Freddi, O. da S. Soil compaction by machine traffic and least limiting water range related to soybean yield. Pesquisa Agropecuária Brasileira, v.43, p.1591-1600, 2008. https:// doi.org/10.1590/S0100-204X2008001100019

Blainski, E.; Tormena, C. A.; Guimarães, R. M. L.; Nanni, M. R. Qualidade física de um Latossolo sob plantio direto influenciada pela cobertura do solo. Revista Brasileira de Ciências do Solo, v.36, p.79-87, 2012. https://doi.org/10.1590/S0100-06832012000100009

Bonelli, E. A.; Bonfim-Silva, E. M.; Cabral, C. E. A.; Campos, J. J.; Scaramuzza, W. L. P.; Polizel, A. C. Compactação do solo: Efeitos nas características produtivas e morfológicas dos capins Piatã e Mombaça. Revista Brasileira de Engenharia Agrícola e Ambiental, v.15, p.264-269, 2011. https://doi.org/10.1590/S141543662011000300007

Bonfim-Silva, E. M.; Paludo, J. T. S.; Silva, T. J. A. da; Guimarães, S. L. Bulk density in jack bean's development grown in Cerrado Oxisol. American Journal of Plant Sciences, v.6, p.1349-136, 2015. https:// doi.org/10.4236/ajps.2015.69134

Busscher, W. J. Adjustment of flat-tipped penetrometer resistance data to a common water content. Transactions of the American Society of Agricultural Engineers, v.33, p.519-524, 1990. https:// doi.org/10.13031/2013.31360

Cavichioli, F. A.; Furlani, C. E. A.; Toledo, A. de; Silva, R. P. da; Ribeiro, C. S. Resistência mecânica do solo à penetração na fileira e entrefileira de cana-de-açúcar em função da mecanização. Engenharia na Agricultura, v.20, p.46-51, 2012. https://doi. org/10.13083/1414-3984.v20n01a06

Collares, G. L.; Reinert, D. J.; Reichert, J. M.; Kaiser, D. R. Qualidade física do solo na produtividade da cultura do feijoeiro num Argissolo. Pesquisa Agropecuária Brasileira, v.41, p.1663-1674, 2006. https://doi.org/10.1590/S0100-204X2006001100013

Collares, G. L.; Reinert, D. J.; Reichert, J. M.; Kaiser, D. R. Compactação de um Latossolo induzida pelo tráfego de máquinas e sua relação com o crescimento e produtividadede feijão e trigo. Revista Brasileira de Ciência do Solo, v.32, p.933-942, 2008. https://doi. org/10.1590/S0100-06832008000300003

Collares, G. L.; Reinert, D. J.; Reichert, J. M.; Kaiser, D. R. Compactação superficial de Latossolos sob integração lavoura-pecuária de leite no noroeste do Rio Grande do Sul. Ciência Rural, v.41, p.246-250, 2011. https://doi.org/10.1590/S0103-84782011000200011

Dane, J. H.; Hopmans, J. W. Pressure plate extractor. In: Dane, J. H.; Topp, G. C. (eds.). Methods of soil analysis: Part 4 - Physical methods. Madison: Soil Science Society of America, 2002. Chap.3, p.688-690. Book Series, 5 .

Fagundes, E. A. A.; Silva, T. J. A. da; Bonfim-Silva, E. M. B. Desenvolvimento inicial de variedades de cana-de-açúcar em Latossolo submetidas a níveis de compactação do solo. Revista Brasileira de Engenharia Agrícola e Ambiental, v.18, p.188-193, 2014. https://doi.org/10.1590/S1415-43662014000200009

Gubiani, P. I.; Reichert, J. M.; Reinert, D. J. Indicadores hídricomecânicos de compactação do solo e crescimento de plantas. Revista Brasileira de Ciência do Solo, v.37, p.1-10, 2013. https:// doi.org/10.1590/S0100-06832013000100001

Guimarães, C. V.; Assis, R. L. de; Simon, G. A.; Pires, F. R.; Ferreira, R. L.; Santos, D. C. dos. Desempenho de cultivares e híbridos de milheto em solo submetido à compactação. Revista Brasileira de Engenharia Agrícola e Ambiental, v.17, p.1188-1194, 2013. https:// doi.org/10.1590/S1415-43662013001100009 
Klein, V. A.; Camara, R. K. Rendimento da soja e intervalo hídrico ótimo em Latossolo Vermelho sob plantio direto escarificado. Revista Brasileira de Ciência do Solo, v.31, p.221-227, 2007. https://doi.org/10.1590/S0100-06832007000200004

Labegalini, N. S.; Buchet, A. C.; Andrade, L.; Oliveira, S. C. de; Campos, L. M. Desenvolvimento da cultura do milho sob efeitos de diferentes profundidades de compactação do solo. Revista de Agricultura Neotropical, v.3, p.7-11, 2016. https://doi. org/10.32404/rean.v3i4.1102

Lima, L. A.; Grismer, M. E. Application of fracture mechanics to cracking of saline soils. Soil Science, v.158, p.86-96, 1994. https:// doi.org/10.1097/00010694-199408000-00002

Lira, R. M.; Silva, Ê. F. de F. e; Simões Neto, D. E.; Santos Júnior, J. A.; Lima, B. L. de C.; Silva, J. S. da. Growth and yield of sugarcane irrigated with brackish water and leaching fractions. Revista Brasileira de Engenharia Agrícola e Ambiental, v.22, p.170-175, 2018. https://doi.org/10.1590/1807-1929/agriambi. v22n3p170-175

Medeiros, J. F. de; Nascimento, I. B. do; Gheyi, H. R. Manejo do soloágua-planta em áreas afetadas por sais. In: Gheyi, H. R.; Dias, N. da S.; Lacerda, C. F. de (eds.). Manejo da salinidade na agricultura: Estudos básicos e aplicados: Fortaleza: INCTSal, 2010. p.279-299.

Medeiros, R. D.; Soares, A. A.; Guimarães, R. M. Compactação do solo e manejo de água I: Efeitos sobre a absorção de N, P, K, massa seca de raízes e parte aérea de plantas de arroz. Ciência e Agrotecnologia, v.29, p.940-9477, 2005. https://doi.org/10.1590/ S1413-70542005000500004

Michelon, C. J.; Carlesso, R.; Petry, M. T.; Melo, G.; Spohr, R. B.; Andrade, J. G. de Andrade. Qualidade física dos solos irrigados de algumas regiões do Brasil Central. Revista Brasileira de Engenharia Agrícola e Ambiental, v.13, p.39-45, 2009. https:// doi.org/10.1590/S1415-43662009000100006

Moreira, W. H.; Tormena, C. A.; Betioli Junior, E.; Figueiredo, G. C.; Silva, A. P. da; Giarola, N. de F. B. Quantificação do intervalo hídrico ótimo de um Latossolo Vermelho utilizando duas estratégias metodológicas. Revista Brasileira de Ciências do Solo, v.38, p.1772-1783, 2014. https://doi.org/10.1590/S010006832014000100015

Ohland, T.; Lana, M. do C.; Frandoloso, J. F.; Rampim, L.; Bergmann, J. R.; Cabreira, D. T. Influência da densidade do solo no desenvolvimento inicial do pinhão-manso cultivado em Latossolo Vermelho eutroférrico. Revista Ceres, v.61, p.622-630, 2014. https://doi.org/10.1590/0034-737X201461050004
Richards, L. A. Diagnosis and improvement of saline and alkali soils. Washington: United States Salinity Laboratory, 1954. 160p. Agriculture Handbook, 60.

Romero, E. M.; Ruiz, H. A.; Fernandes, R. B. A.; da Costa, L. M. Condutividade hidráulica, porosidade, resistência mecânica e intervalo hídrico ótimo em Latossolos artificialmente compactados. Revista Brasileira de Engenharia Agrícola e Ambiental, v.18, p.1003-1009, 2014. https://doi.org/10.1590/18071929/agriambi.v18n10p1003-1009

Romano, N.; Hopmans, J. W.; Dane, J. H. Suction table. In: Dane, J. H.; Topp, G. C. (eds.). Methods of soil analysis: Part 4 - Physical methods. Madison: Soil Science Society of America, 2002. Chap.3, p.692-698. Book Series, 5

Ross, P. J.; Willians, J.; Bristow, K. L. Equations for extending water-retention curves to dryness. Soil Science Societies American Journal, v.55, p.23-927, 1991. https://doi.org/10.2136/ sssaj1991.03615995005500040004x

Silva, A. O. da; Klar, A. E.; Silva, E. F. de F. e; Tanaka, A. A.; Silva Junior, J. F. Relações hídricas em cultivares de beterraba em diferentes níveis de salinidade do solo. Revista Brasileira de Engenharia Agrícola e Ambiental, v.17, p.1143-1151, 2013. https://doi. org/10.1590/S1415-43662013001100003

Silva, A. P. da; Kay, B. D.; Perfect, E. Characterization of the least limiting water range. Soil Science Society of America Journal, v.58, p.1775-1781, 1994. https://doi.org/10.2136/ sssaj1994.03615995005800060028x

Simões, W. L.; Calgaro, M.; Coelho, D. S.; Santos, D. B.; Souza, M. A. de. Growth of sugar cane varieties under salinity. Revista Ceres, v.63, p.265-271, 2016. https://doi.org/10.1590/0034737X201663020019

Souza, G. S. de; Souza, Z. M. de; Silva, R. B. da; Barbosa, R. S.; Araújo, F. S. Effects of traffic control on the soil physical quality and the cultivation of sugarcane. Revista Brasileira de Ciência do Solo, v.38, p.135-146, 2014. https://doi.org/10.1590/S010006832014000100013

Toledo, J. V.; Zolnier, S.; Silva, T. G. F .da; Boehringer, D.; Steidle Neto, A. J. alterations on the evapotranspiration of sugarane cultivars under distinct salinity levels applied in the fertigation. Engenharia Agrícola, v.37, p.940-952, 2017. https://doi.org/10.1590/18094430-eng.agric.v37n5p940-952/2017

Tormena, C. A.; Silva, A. P.; Libardi, P. Caracterização do intervalo hídrico ótimo de um Latossolo Roxo sob plantio direto. Revista Brasileira de Ciência do Solo, v.22, p.573-581, 1998. https://doi. org/10.1590/S0100-06831998000400002 